\title{
Henry Mintzberg's Business Management Strategy Post-Pandemic Covid-19 (Social Learning Approach on Ali Murah Shop Madinah)
}

\author{
Fania Mutiara Savitri ${ }^{*}$, Yuris Tri Naili ${ }^{2}$ \\ ${ }^{1}$ Universitas Islam Negeri Walisongo Semarang, Indonesia; ${ }^{2}$ Universitas Harapan Bangsa, Indonesia \\ *e-mail: faniamutiara@walisongo.ac.id
}

\begin{abstract}
Small Micro Enterprises in retail sector is currently faced many problems, declining sales, difficulty in obtaining supplies, impeded dilivery and distribution, lack of information technology knowledge and business network barriers. This study aims to determine the business management strategies of Ali Murah Shop Madinah post Covid-19 pandemic as retail practice description in Madinah, Saudi Arabia. The study refers to Henry Mintzberg strategy (position, plan, perspective, project, dan prepare). Research type is descriptive and data collection methods using structured interviews conducted to 3 informan. This research also used social learning approaches to get deeply analysis. The data analysis technique used descriptive qualitative. The results of the study explained that business management strategy post pandemic Covid-19 Ali Murah Shop Madinah can be implemented in order to get improvement and sustainable development attached by management strengthening in marketing, human resources, finance and operations field as strategic steps to create an efficient and effective business existence. Furthermore, regarding social learning approaches, Ali Murah Shop Madinah are required to have good knowledge management and absorptive capacity especially in protocol which prevent Covid-19 transmission. Future research is expected to get empiricaly analysis for objective result obtaining that also supported by quantitative and qualitative analyze (mix methods)..
\end{abstract}

Keywords:

Strategy; Business Management; Social Learning; Post Covid 19 Pandemic.

\begin{abstract}
ABSTRAK
Usaha Mikro Kecil di sektor ritel saat ini menghadapi banyak kendala, penurunan penjualan, kesulitan mendapatkan pasokan, terhambat dilivery dan distribusi, minimnya pengetahuan teknologi informasi dan hambatan jaringan usaha. Penelitian ini bertujuan untuk mengetahui strategi manajemen bisnis Toko Ali Murah Madinah pasca pandemi Covid-19 sebagai analisis deskripsi praktik ritel
\end{abstract}


di Madinah, Arab Saudi. Studi tersebut mengacu pada strategi Henry Mintzberg (posisi, rencana, perspektif, proyek, dan persiapan). Jenis penelitian adalah deskriptif dan metode pengumpulan data menggunakan wawancara terstruktur yang dilakukan kepada 3 informan. Penelitian ini juga menggunakan pendekatan pembelajaran sosial untuk mendapatkan analisis yang mendalam. Teknik analisis data menggunakan deskriptif kualitatif. Hasil penelitian menjelaskan bahwa strategi manajemen bisnis pasca pandemi Covid-19 Ali Murah Shop Madinah dapat dilaksanakan guna mendapatkan perbaikan dan pembangunan berkelanjutan yang disertai dengan penguatan manajemen di bidang pemasaran, sumber daya manusia, keuangan dan operasional sebagai langkah strategis untuk menciptakan keberadaan bisnis yang efisien dan efektif. Selanjutnya terkait pendekatan pembelajaran sosial, Ali Murah Shop Madinah dituntut memiliki manajemen pengetahuan dan daya serap yang baik terutama dalam protokol yang mencegah penularan Covid-19. Penelitian selanjutnya diharapkan mendapatkan analisis empiris untuk memperoleh hasil yang obyektif yang juga didukung oleh analisis kuantitatif dan kualitatif (metode campuran).

\section{Kata kunci:}

Strategi; Manajemen bisnis; Pembelajaran Sosial; Pasca Pandemi Covid 19.

\section{Introduction}

The Covid-19 pandemic threatens human health over the world. Data shows there are 6,981,651 people in the world infected with corona virus, Saudi Arabia with a number of population, around 98,869 people are infected. Medina Province around 10,822 people are also infected, 61 of them died and 9,544 people were recovered (en.m.wikipedia.org). The existence of a severe recession due to a pandemic requires a combination of monetary policy and expansionary fiscal policy. These steps have been taken by the government of Saudi Arabia Kingdom together with its monetary authority to fight against Covid-19 pandemic (Sikki, 2020). The Saudi Arabia government provides financing facilities for SMEs as working capital through one of its monetary policies. Therefore, financial access is not the main barrier for SMEs to face the Covid-19 pandemic. Saudi Arabia kingdom's internationalpolicy provides assistances to WHO in order to overcome Covid-19 pandemic problem. This behavioral principal based on the Qur'an teaching about persuading people to perform important thing by sharing our earn to others (infaq) in difficult situation (QS An-Nur: 33).

Increasing number of infected people has an impact on economic aspects such as panic buying, tourist resort which is getting weak, and decreasing all sales transactions. Government and all the people are currently required to prepare themselves for facing these emergency situations. They should act responsively anticipating the impact of Covid-19 on whole business sector. The enactment of LSSR (Large-Scale Social Restrictions) and the application of Work From Home (WFH) for both private and government employees affects bring effect on public revenue. Not only that, it also brings domino effect on Micro and Small and Medium Enterprises performance (Hadi and Supardi, 2020). 
These problems require stakeholders to work together maintaining SME's sustainability and performance recovering after the Covid-19 pandemic by handling SME's commitment and trust concistenly (Hadi et al, 2020). To reduce the negative impact on the retail sector SMEs requires appropriate and rapid innovation to create new activities to continue ensuring the business sustainability (Septina, 2020). By utilizing digital technology such as social media and online shops as an alternative solution due to goverment regulation. Many department store, mall and public fasicilies who have big potential for virus transmitting are forced to closed by the government. Some of them got work contract breaking, some others implement LSSR and WFH. This situation causes SME's owners are faced with the issue of entity loss.

A strategy demonstrating the existence of Ali Murah Shop Madinah after the Covid-19 pandemic is proposed by Henry Mintzberg. He defined the strategy as 5P, namely (position, plan, perspective, project, and prepare). Pedersen and Ritter (2020) explain that the definition of Strategy as a plan before it is implemented and followed up through practical activity. Strategy as a special preparation activity that distinguishes the owner business strategies with competitors in order to optimizing competitiveness. Strategy is a project means this strategy provide solution for future and prospective user. Strategy as a pattern shows a company's activities that can be explained through patterns that emerge from activities that have been planned and carried out previously. Strategy as a position, business actors can use existing resources, both physical and knowledge to provide a unique product to find a niche market that aims to hinder and outperform competitors. Finally, strategy as perspective refers to the organizational culture of business people to view themselves and their environment as a strategy.

The importance of business management for MSEs can be seen in several areas of management strengthening, such as marketing, human resources, finance and operations (Wahyuni, Endang, and Wibawani, 2020). In marketing strengthening, digital marketing systems need to be developed effectively and reach wider community (Rangkuti, 2013; Tasruddin, 2015). For example, by applying conventional marketing concepts and digital marketing such as marketing efforts on social media in additional such as Facebook, Instagram, Whatsapp or other social networks. In human resource management strengthening, increasing knowledge, insight and skills will provide capability to manage their business have good readiness and well organized (Sandiasa and Widnyani, 2017).

Strengthening financial aspect generally includes effective and efficient financial management related to capital access and bookkeeping / financial administration (Putri, 2018; Setyawardani, et al, 2019). Finally, strengthening operational management area includes improving quality, cost efficiency and appropriate distribution targets. This study aims to confirm the 5P theory from Henry Mirtberg through the list of questions provided to informan. This study also explores the answers to the questions raised by Pedersen and Ritter (2020) 5 (five) Ps, namely: position, plan, perspective, project, and prepare adapted to the 5P theory from Henry Mintzberg. The following questions can guide business owners for crisis recovery project so that SME can take appropriate steps to save their business due to the Covid-19 pandemic. 
All the conveniences that is taken by the kingdom of Saudi Arabia, both monetary and fiscal policies, are sufficiently felt as a form of government support in overcoming the situation arising from the Covid-19 pandemic. Not only made it easier for the country, the King also contributed to WHO through donations alleviating all countries in the world to fight against a pandemic. Further more, certain policies of Saudi Arabia Kingdom is the limitation tourists entry and the Umrah prayer from local and abroad visitor are totally closed. Mosques are temporarily no longer open for prayer five times a day and Friday prayers. These policies will have negative implications on the economy both at the macro and micro scales, the main reason implementing these policy is to prevent bigger Covid-19virus transmission (Sikki, 2020). The existence of a gap phenomenon about Government policy perceived as good and bad news by the people. The bad news raises the problem on decreasing SME's sector income especially directly felt by the tourism sector that rely on from tourists visiting activities in Medina.

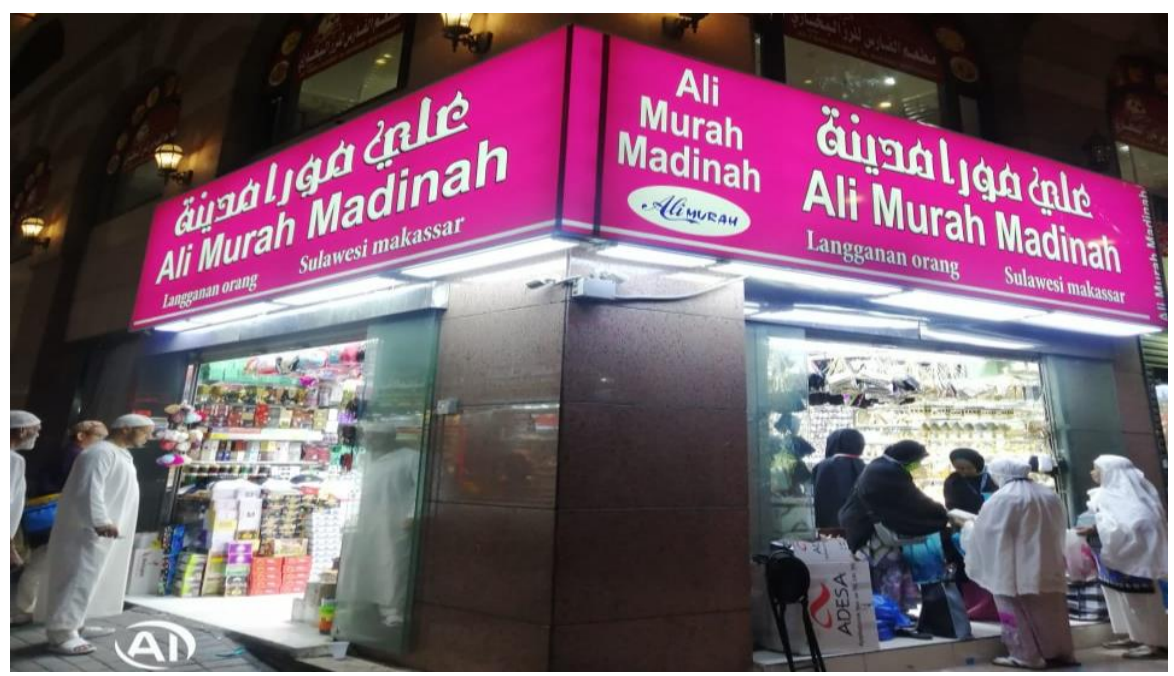

Picture.1 Ali Murah Shop Madinah

Ali Murah Shop is one example of SME's in retail sector that was affected by Saudi Arabian policy. The store is located in Madinah Munawarah under the Bahauddin Hotel Gate of Masjid 25. The shop sells Hajj / Umrah needs and unique arabian souvenirs for tourists from all over countries who visit the Prophet's Mosque. There are hundreds of shops in the vicinity of the Nabawi Mosque that are affected by the pandemic which has decreased in overall performance. This study selects objects in the store as a case study considering that the store has better endurance compared to other stores. 


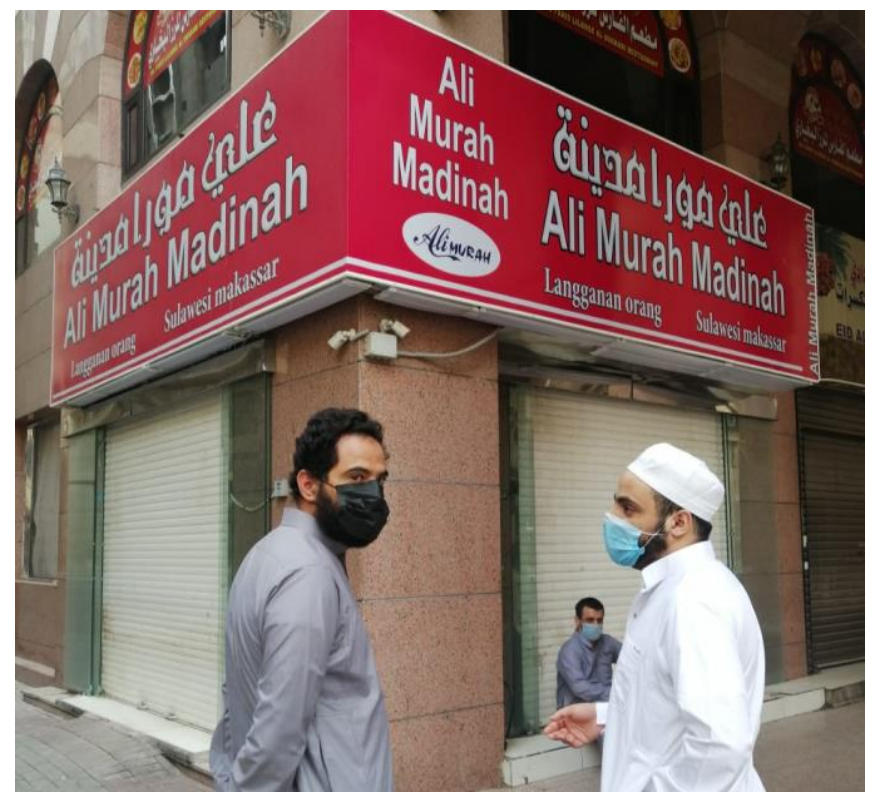

Picture 2. Ali Murah Shop is Closed

Pandemic situation maked all SME closing their outlets because it had no visitor, but Ali Murah Shop persisted in providing services until there was really a ban from the kingdom to close the shop tightly. In addition, Ali Murah Shop also has a good business network with customers. Based on interviews with Hamid Mohamed Ali as owner, there was a sales decrease in last 5 months. In February, sales decreased 12.97\%; March and April sales decreased 54.07\% and 86.70\% from previous month and finally no sales in May. June was predicted to be a turning point against Pandemic. All policies were taken by Saudi Arabia Kingdom to restore economic into normal condition. Therefore, it is necessary to know what kind of strategy that is carried out by microsmallscale retailers in returning retail performance which has been experiencing a decline in sales.

Regarding phenomena background mentioned in the introduction, this study aims to determine the Ali Murah Shop's business management strategies and to find out the barrier and solution its business strategy post-pandemic Covid-19.

\section{Method}

This study uses qualitative methods with in-depth interviews as data collecting method. These interviews are conducted through Chat, Phone Call, Video Call via Whatsapp as needed. There are many interview steps, start from the researchers sending requests for data collection via short messages that contain about the identity of the researcher and the reasons for conducting research, asking permission to publish data, taking photos, and asking informan time making further contact (Rowley, 2009). The next stage is sending questions to informan to ensure the willingness to be interviewed. The questions in the interview are based on Henry Mintzberg's theory which adapts the framework in five question concepts (5 Ps strategy) which includes:

1. What position do you want to achieve after the pandemic?

2. What are your plans as a business actor to get back up?

3. Will your business culture and identity change? 
4. What is your new project that will be launched?

5. How ready are you to carry out these plans and projects?

The number of respondents in this study as many as 3 people (business owner Ali Murah shop Madinah and 2 shopkeeper). There is limitation getting customers as informants for objective result due to hard condition (post-lock down).

This research used descriptive qualitative research techniques that describe and explain the data that has been collected by observing and recording many aspects as possible so that it gets an overall picture of the actual conditions (Creswell, 2016). The steps of qualitative data analysis in this study are: data collection, data reduction, data presentation and display and verification of conclusions.

\section{Result and Discussion}

Data collection in qualitative descriptive research was carried out when doing online observation in the field. Data collection was conducted by researchers through interview transcripts from Phone Call, Video Call chatting via Whatsapp from 3 respondents. After the data collection was completed, the results are catagorized according to the questions in the study regarding the position, plan, perspective, project and prepare. Data reduction stage shows the activity selecting the notes or results of the interview. The data passed through the reduction phase through a series of interviews with informant/respondents regarding marketing, human resources, finance and operations. The data has been reduced from information in order to facilitate the conclusion. Research data can be presented in description form supported by previous research with relevant theories related to Covid19 post pandemic's business management strategies. The data and information that has been collected, reduced and presented should be easily understood. Then conclusions based on results analysis of the interview to the informan. During the research process, data obtained from the owner of Ali Murah Shop Madinah. Next step the data was collected, studied for processing and then analyzed. This research analysis have found information which is relevant to theories and previous research as reference sources.

In post-pandemic, Ali Murah shop is tried hard to recover the sales. There is great owner's optimism it will bring success because Ali Murah Shop have strong network and has boult engagement with customer throug social media in many countries.

\section{Business management Strategy post-pandemic Covid-19 Ali Murah Shop Madinah}

The finding of the analysis related to the retail business strategy post the Covid-19 pandemic are: The position strategy, the position of retail business owner Ali Murah Shop Madinah post pandemic is developing the excelence marketing strategy to achieve sales targets and better services in same location choice including stunning name and tag line presented. Planning and developing business products include providing affordable prices must attract consumers. Determination of the product distribution channel excactly is beneficial for surpassing competitors. Pandemic is one of the environmental changing, it requires serious learning for busnisman to take action faster by improve their dinamic capability to absorb many information related positioning strategy in order to be 
stunning shop. The strategic plan, strategic plan for the retail businesses sustainability emerging from the Covid-19 pandemic is to focus on resources that are always available quickly and appropriately, potential human resources / shopkeeper who have much understading about product knowledge, work systems stores, information systems and good communication with customers. Then, it also requires facilities availablity in utilizing technology, access and services to customers will become the main focus in planning or designing retail businesses going forward. Shopkeeper informans as human resources indicate a good loyalty and having high engagement at the shop where they work as owner's expectation. Regarding shopkeeper behavior, Ali Murah Shop Madinah can provide more satisfying services for consumers afterwards. The results of this study differ from Sumiati, Rofiq, and Promono (2019)'s finding which explains that a mature planning-based strategy plays an important role as mediation in influencing consumer-oriented business performance but this research finding convince that by utilizing existing resources and empowering them as unique resources in achieving competitive advantage, it is also related to the Resource Based View theory developed by Barney.

The perspective strategy explains SME's views in terms of organizational identity and culture. This perspective will improve the retail businesses performance that observer are enough trust and paid attention on it. High efforts from business owner and consumers will improve business performance and be responsible for the business growth. Businessman should commit on value and culture that business organization must have a clear mission, the involvement of superiors and consistency in running the business. Businesman see the Covid-19 pandemic as a challenge as well as an opportunity in developing their business. Many new things they got during this pandemic, knowledge about consumer behavior to deal with the pandemic and the behavior of SMEs in responding to this pandemic. Consistent with research conducted by Sternad, Krenn, and Schmid (2017) which explains that SMEs must respond to customer complaints, customer needs and markets sensitivity to achieve business excellence. The objectives to be achieved must be understood by organization members (business owner and his six employees). Target achieving by organization member according to goal setting theory that requires hard work to be done cooperatively by individuals in the organization (Locke \& Latham, 2012).

Strategy as a project, encouraging retail businesses to start new business activities as a strategy to respond post Covid-19 pandemic recovery in various ways, for example, diversifying products to maintain business and developing support systems in order to gain business profits. Support system can be done through starting promotions through social media (Facebook, Instagram and WhatsApp groups). This promotion is trying to get feedback from the future visitor. Promotion projects through social media make product descriptions clear and improve brand image popularity. In addition, business owners also try to build partnerships by planning to open branches in Makassar City, Indonesia. Promotion through social media was discussed has same meaning with Pradana (2015) who explained about electronic commerce (e-commerce). The electronic promotion strategy able to run well by implementing the 4C principles, namely: connections, creation, consumption and control. These principles encourage competitiveness and provide business margins, approved active participation such as consumer feedback or reviews, and getting support for other users. The project 
strategy is also related to the resource-based view theory, by the use of unique resources possessed to achieve competitive advantage. Promotion activities by utilizing technology become their creativity and innovation (Müller, 2018). This finding is consistent with previous research which states that electronic based SMEs have different business strategies than SMEs who use conventional strategy in conducting their business (Helmalia and Afrinawati. 2018; Shahzad et al, 2020)

Strategy as preparing, SMEs basically do not have the readiness to face the Covid-19 pandemic yet. Beased on social learning approach, SMEs are required to have an absorptive capacity to get as much information about the Covid-19 pandemic. They will easily understand consumer behavior, business behavior and government policy so they can prepare faster to continue their business properly. For example, the opening of the Ali Murah Shop in early June 2020 implements social distancing, provides hand sanitizers and requires waiters and visitors to wear masks. Consistent with Haa, Lob, and Wang (2016) finding which explains that the knowledge management process provide insights to entrepreneurs to help them identify and develop effective strategies to improve their overall performance. The absorptive capacity will direct retail businesses to achieve the other four strategies. In this research, retail businesses are encouraged to develop their ability to manage knowledge that will move them to become more competitive and innovative. The results of his research indicate that knowledge management process capability is the most important antecedent of the performance (financial and non-financial) especialy in retail small business sector (Oktafia and Hidayat, 2018). Furthermore, resource based view theory has a perspective that when an organization does not have valuable and unique resources and capabilities, it cannot be imitated and organized, then the organization must use outsourcing resources to overcome these weaknesses (Cahyaningtyas and Ningtyas, 2020). It means that the resources of the organization must have strength and endurance to be competitive and sustainable. Then these resouces is channeled and absorbed to all organization member to be processed well so the organization have preparation to obtain and sustain competitive advantage on an ongoing basis.

\section{Barriers and Solutions Post-Pandemic Covid-19 Business Management Strategy Ali Murah Shop Madinah}

First, Ali Murah Shop Madinah's problem is about business sustainability. It is due to limited market access and business networks. Thats why sales growth are difficult to achieve. It causes the most of business actors to be more patient to run and continue their business properly. However, these limitations can be the basis to set the goal to improve work performance in the future, according to the goal setting theory that has written above that setting goals in challenging phase (difficult) will force busineman take action better, suppose looking for solution for many barrier, etc. Setting measurable results will also be able to improve work performance, which is followed by having better work abilities and skills. Respondents who have good knowledge management and absorptive capacity are able to accumulate various information and knowledge from various information media that develop so quickly that they can make preparations and arrange strategies again to start, continue, and develop business such as through direct sales promotions and through digital media such as 
Facebook, Instagram, and WhatsApp by making and displaying unique interesting content for customers (Prastiyanti, Dinda, and Yulianto, 2019).

Second, the problem related human resource management on Ali Murah Shop Madinah post Covid-19 pandemic are the lack of knowledge, skills and insights in utilizing available technology to increase business productivity. This pandemic requires employee adapt to current conditions, one of adaptation form is they must be able to utilize existing technologies such as selling online using social media, increasing the quality of service to consumers, and diversifying products or services to improve business performance. The application of new normal by the kingdom abled to help the Ali Murah Shop Madinah to overcome the retail businesses barriers. The implementation of new normal retail businesses should be absorbed seriousely and plan well, it is a must in understading Covid-19 protocol such as keep their distance from other people, wear masks, use hand sanitizers and regularly spray disinfectan. Briefing to employees is one of the way starting this protocol to develop new normal business strategy.

Third, financial management recovery is a financial aspect problem due to policies and regulations set by the government during the Covid-19 pandemic. Debt overdue requires them to restructure payment policy agreements. Some informants revealed that the Ali Murah Shop has less good and safe financial book keeping without applicable accounting standards. Based on information, financial record manually on paper even some of it rely on their minds. The employees's salary payment had to be deducted and some employees were repatriated. The repatriated due to less visitors in the shop. Although the Covid-19 protocol implemented, the shop still show slow motion that reduce shop revenue. Related to this problem, Ali Murah Shop owner is expected to be wise in managing finances for business sustainability post-pandemic Covid-19. Furthermore they are also expected to calculate labor costs fairly while still using all employees but with the shift method.

Finally, the bariers faced in operational management. There were lack of goods supply availability during the Covid-19 pandemic, delay of distribution and delivery. Cutting the product distribution chain by carrying out distribution activities themselves to reduce the costs can be solution. Management can easily ensure the quality of their products themselves and set lower prices because they are directly involved from the upstream to downstream processes.

\section{Conlusions}

In order to realize and develop the SME's sustainability post Covid-19 pandemic, it is necessary to achieve a mature strategy and achieve strategy realization itself. This strategy would give good results on strengthening business management in marketing, finance, human resources and operational. Business actors optimism continue and improve their business by running effective business management strategies. One of these strategies is the implementation of the 5P strategy (position, plan, perspective, project, and prepare) as an effort to be able creating more efficient and effective business existing. Moreover, the important thing that should be had by SME's retail sector owner is having good knowledge management and absorptive capacity to improve business performance. In detail, Henry Mintzberg's 5P strategy is as follows: 1) Achieve better sales and 
service targets at the same location choice with the same retail display position (Position); 2) Consumer-oriented by utilizing existing resources (Plan); 3) SME's perspective in the identity and involvement of superiors as well as consistency with retail service commitments (Perspective); 4) Starting a new business activity (partnership \& e-promotion) as a responsive strategy to recover conditions after the Covid-19 pandemic (Project); 5) Business actors are required to have absorptive capacities to get many informations about the Covid-19 pandemic and protocol to predict consumer behavior. It is useful to achieve the success of the other strategies (Prepare).

Pandemic Covid-19 raises SME's issues in marketing, human resources, finance and operations. Knowledge management is needed to think critically making a deal with the Covid-19 pandemic and prepare appropriate strategies for marketing, finance, operations and human resources that are used in post pandemic period. Dinamic capability is one of important knowledge management regarding the essential of social learning. This study has several limitations, first, the perceptions analysis has been collected from limited informans that cannot be validated through triangulation method. Second, this research is a case study thay only analyze a SME in retail sector, Ali Murah Shop Madinah, it only obtains a practical response subjectively because the object of research is only single retail in Medina. Therefore future research agenda are using many informants (include customer perceptions) and catagorized through codes for deeply qualitative analysis and it also expected to conduct empirical studies in several and various retails in Medina in order to get objective practical responses and provide better benefits.

Some practical implications able to support research solutions. The Saudi Arabia's government is expected to issue policies immediately that strengthen the Islamic tourism sector, so that it can soonly encourage retail sales. The concept of e-commerce should be used also during and after a pandemic. These effort will improve retail performance and convince the retail weakness due to pandemic is recoved well continuously. By using this e-commerce concept, it will make the Ali Murah Shop Madinah better known through the digital platform and can increase SME's income or at least make it well known about its retail brand awareness. In addition, the application of ecommerce is related to the theory of resource-based view that can be applied after this pandemic, this theory optimizes human resources for competitive advantage through personal branding. Next step, boosting personal branding by collaborating with influencers in each country to help promote and recommend the Ali Murah Shop Madinah as souvenir solutions and souvenirs of Islamic tourism in Medina, Saudi Arabia.

Theoretically, this research contributes in business management dicipline especially the business preparation strategy after the Covid-19 pandemic through social learning approache. Furthermore, future research is expected to examine more sources and references, suppose by increasing analyse scope and conduct empirical deeply analysis by using a mixed method, it means the research method use quantitative and qualitative methods. 


\section{References}

Barney, J. B., \& Clark, D. N. (2007). Resource-based theory: Creating and sustaining competitive advantage. Oxford University Press on Demand.

Cahyaningtyas, F., \& Ningtyas, M. N. (2020). Akuntan Outsourcing dan Kinerja UMK: Perspektif Resource Based View. Jurnal Riset dan Aplikasi: Akuntansi dan Manajemen, 4(2), 167-182.

Chaniago, S. A. (2014). Perumusan Manajemen Strategi Pemberdayaan Zakat. Jurnal Hukum Islam, 12(1), 87-100.

Creswell, Jhon W. (2016). Research Design: Qualitative, Quantitative, and Mix Methode Approach. Fourth Edition. SAGE Publication.

Haa, S Tong., Lob, M Chiun., dan Wang, Y Chai. (2016). Relationship between Knowledge Management and Organizational Performance: A Test on SMEs in Malaysia. Procedia- Social and Behavioral Sciences 224 (2016) 184 - 189.

Hadi, S., dan Supardi. (2020). Revitalization Strategy for Small and Medium Enterprises after Corona Virus Disease Pandemic (Covid-19) in Yogyakarta. Xi'an Jianzhu Keji Daxue Xuebao/Journal of Xi'an University of Architecture \& Technology. April 2020.

Hadi, S., Tjahjono, H. K., dan Palupi, M. (2020). Study of Organizational Justice in SMEs and Positive Consequences: Systematic Review. International Journal of Advanced Science and Technology, 29 (03), 14.

Helmalia dan Afrinawati. (2018). Pengaruh E-Commerce Terhadap Peningkatan Pendapatan Usaha Mikro Kecil Dan Menengah di Kota Padang. Jurnal Ekonomi dan Bisnis Islam, Vol. 3 No.2.

https://en.m.wikipedia.org/wiki/Template:COVID-19_pandemic_data

Khotimah, K. (2017). Pandangan berbasis sumber daya (RBV) dalam pembahasan organisasi ekonomi. Masa Depan: Jurnal Manajemen dan Akuntansi, 5 (1), 178003.

Locke, E. A., \& Latham, G. P. (2012). Goal setting theory. In Motivation: Theory and research (pp. 23-40). Routledge.

Müller, J Marius. (2018). Business model innovation in small- and medium-sized enterprises Strategies for industry 4.0 providers and users. Journal of Manufacturing Technology Management, Vol. 30 No. 8, 2019 pp. 1127-1142

Oktafia, R., dan Hidayat, AR. (2018). Penguatan Kapasitas Pelaku Bisnis Mikro Melalui Penataan Pengelolaan Keuangan Usaha: Pandangan Islam. Jurnal Masharif al syariah: Jurnal Ekonomi dan Perbankan Syariah, Vol. 3 No. 2 
Pedersen, C., Lund dan Ritter, T. (2020). Preparing Your Business for a Post-Pandemic World. Hardvard Business Review.

Pradana, M. (2015). Klasifikasi jenis-jenis bisnis e-commerce di Indonesia. Neo-Bis , 9 (2), 32-40.

Prastiyanti, Dinda P., dan Yulianto. (2019). Media Promosi Pada Dinas Pariwisata Daerah Istimewa Yogyakarta Dalam Meningkatkan Kunjungan Wisatawan. Journal of Indonesian Tourism, Hospitality and Recreation, Volume 2, No. 2, October 2019

Putri, E. (2018). Pelatihan Pengembangan Diri Menjadi Wirausaha Mandiri dalam Efisiensi dan Efektifitas Produksi Karak Herbal di Cinderejo Kidul, Gilingan, Surakarta.

Rangkuti, F. (2013). Strategi promosi yang kreatif dan analisis kasus: Gramedia Pustaka Utama.

Rengkung, LR (2015). Keuntungan Kompetitif Organisasi dalam Tampilan Berbasis Sumber Daya Perpsektif (RBV). Agri-Socioekonomi, 11 (2A), 1-12.

Rowley, Jenifer. 2009. Conducting research interviews. Management research review, 35 nomor 3/4 (1): 260-271.

Sandiasa, G., dan Widnyani, I. A. P. S. (2017). Kebijakan Penguatan Lembaga Pemberdayaan dalam Meningkatkan Partisipasi Pemberdayaan Masyarakat di Perdesaan. Dalam Locus Majalah Ilmiah Fisip, 8, 64-78.

Savitri, F. M., \& Indarto, I. Mediating Role of Strategy in the Relationship between Organization Learning and Business Performance. Jurnal Studi Manajemen Organisasi, 17(1), 1-19.

Septina. (2020). 7 Strategi Pemasaran Produk UKM saat Krisis Virus Covid-19. Jurnal Blog. https://www.jurnal.id/blog/7-strategipemasaran-produk-ukm-saat-krisis-virus-covid-19. 95

Setyawardani, T., Widayaka, K., Sularso, K. E., dan Wakhdiati, Y. (2019). Wirausahawan Muda Mandiri dengan Program Pengembangan Kewirausahaan di Universitas Jenderal Soedirman. Jurnal Surya Masyarakat, 2(1), 50-57.

Shahzad, A., Chin, HK. (2020). Malaysian SMEs Performance and the use of E- Commerce: A MultiGroup Analysis of Click-and-Mortar and Pure-Play E-Retailers. Pakistan Journal of Commerce and Social Sciences 2020, Vol. 14 (1), 01-33.

Sikki, K. L. (2020). Kebijakan Ekonomi Arab Saudi dalam Mengantisipasi Pandemi Covid-19. Journal of Islamic Civilization, 2(1), 8-16.

Simatupang, B. (2013). Tinjauan Komplementer Pengaruh Teori Tampilan Berbasis Pasar (MBV) dan Tampilan Berbasis Sumberdaya (RBV) terhadap Strategi dan Kinerja Perusahaan. Binus Business Review, 4 (1), 322-330. 
Sternad, D., Krenn, M., dan Schmid, S. (2017). Business excellence for SMEs: motives, obstacles, and size-related adaptations. Total Quality Management \& Business Excellence, DOI: 10.1080/14783363.2017.1300054.

Sumiati, Rofiq, A., dan Pramono, S. (2019). The Role of Strategic Planning and Flexibility in Shaping SMEs Market Orientation in Turbulence Business Environment. European Research Studies Journal Volume XXII, Issue 1, 2019 pp. 221-236.

Tasruddin, R. (2015). Strategi Promosi Periklanan yang Efektif. Jurnal Al-Khitabah, 2(1).

Wahyuni, Endang D., dan Wibawani, S. (2020). Pemberdayaan Pengurus Aisyiyah dengan Penguatan Manajemen Bisnis. Jurnal Pengabdian dan Peningkatan Mutu Masyarakat, vol 1 no 1, p. 1317. http://ejournal.umm.ac.id/index.php/janayu. 